\title{
COMPUTATIONAL FLUID DYNAMICS INVESTIGATION OF SOLAR ACTIVATED CARBON AIR FILTER
}

\author{
Ibrahim Mohammad Awad Mustafa ${ }^{1}$, Krunal Patel ${ }^{2}$, Khaled Alzahrani ${ }^{3}$ \\ ${ }^{I}$ Chemical Skills Department, Yanbu Technical Institute, Yanbu Al-Sinaiyah, Saudi Arabia \\ ${ }^{2}$ Advance Computational Lab, Yanbu Research Center, Yanbu Al-Sinaiyah, Saudi Arabia \\ ${ }^{3}$ Mechanical Engineering Technology Department and Yanbu Research Center, Yanbu Al-Sinaiyah, Saudi Arabia \\ E-mail:mustafaim@rcyci.edu.sa
}

\begin{abstract}
The solar energy is the language of this age. It is renewable, clean and almost without cost. This research is focusing on utilizing of renewable energy in air purification process. As known, our environment is full with industrial waste gases, such as $\mathrm{SO}_{\mathrm{x}}, \mathrm{NO}_{\mathrm{x}}, \mathrm{CO}_{\mathrm{x}}$, $\mathrm{CH}_{4}, \mathrm{H}_{2} \mathrm{~S}$ etc. To reduce percentage concentration of these gases, solar energy is used to generate a convection stream within a metal black column. Polluted air consists of industrial waste gases, while passing through the column, it will contact with baffles of an activated carbon plates, fixed horizontally to increase the contact area with gases. The activated carbon is a common adsorbent with tremendous adsorption capability. So it will remove waste gases from polluted air. The three-dimensional steady-state continuity, Navier-Stokes, energy, radiation, natural convection, species transport for $\mathrm{CO}_{2}$ physical adsorption and multiphase Eulerian-granular model equations are solved under turbulent condition, using the commercially available Computational Fluid Dynamics software Fluent. The quality of the solutions obtained from these simulations is largely within the acceptable range proving that Computational Fluid Dynamics is an effective tool for predicting the behavior and performance of a solar air filter.
\end{abstract}

Keywords: Solar air filter, $\mathrm{CO}_{2}$ species transport, Activated carbon.

\section{INTRODUCTION}

The atmospheric concentration of $\mathrm{CO}_{2}$ has increased dramatically over the last two centuries, and this increase has a significant impact on the environment, contributing to climate change and the acidification of the oceans. Researchers and scientists agree that a decrease in $\mathrm{CO}_{2}$ emissions into the atmosphere is highly desired. Carbon dioxide capture and storage (CCS) is attracting attention lately as a measure for reducing $\mathrm{CO}_{2}$ gas emissions substantially and rapidly [1]. The adsorption method is a promising alternative to chemical absorption due to its advantages in terms of energy savings and ease of operation. Three key requirements must be met to develop $\mathrm{CO}_{2}$ adsorbents: (a) ability to adsorb a large amount of $\mathrm{CO}_{2}>4.4 \mathrm{wt} \%$ (b) extended working life, (c) low energy demands for regeneration [2]. Activated carbon has been most extensively used for $\mathrm{CO}_{2}$ adsorption due to their high specific surface area and good physicochemical properties. Moreover, the performance of carbon materials as adsorbents depends on the combination of porous and chemical surface properties [3]. However, the higher adsorption capacity of $\mathrm{CO}_{2}$ on activated 
carbon was obtained at a lower temperature. The activated carbon used in this research is the activated charcoal. It is a form of carbon processed to have small, low volume pores that increase the surface area available for adsorption process, due to its high micro porosity, just one gram of this activated carbon has a surface area in excess of $500 \mathrm{~m}^{2}$ [4]. There are number of researchers work on fixed bed solid adsorption process to separate solvent vapour. Takeuchi et al practically proved that the effect of solvent vapor was governed by surface diffusion for air having velocity above $0.2 \mathrm{~m} / \mathrm{s}$ [5]. Eventually, JeanNoel Baleo et al numerically and experimentally compared pressure drops in carbon cloths adsorption medium [6]. Two groups experimentally studied the $\mathrm{CO}_{2}$ adsorption thermodynamics effect at different temperatures by using vacuum adsorption apparatus [7-8]. Pressure swing adsorption process with activated carbon bed to extract carbon dioxide and methane from pure gases was experimentally studied by Goetz et al at two different temperatures (273 and $298 \mathrm{~K}$ ) and for pressure up to $1 \mathrm{MPa}$ [9]. Pevida et al performed an experiment to study surface modification effect of activated carbon on $\mathrm{CO}_{2}$ capture through X-ray photoelectron spectroscopy [10]. Berger and Bhown developed a theoretical model for optimizing solid sorbent for $\mathrm{CO}_{2}$ capture [11]. One of the researchers who performed experiments on activated carbon and zeolite $13 \mathrm{X}$ for $\mathrm{CO}_{2}$, $\mathrm{N}_{2}$ and $\mathrm{CH}_{4}$ [12]. Hauchhum and Mahanta also followed same procedure with Zeolites 13X, zeolite $4 \mathrm{~A}$ and activated carbon using temperature swing adsorption method [13]. The maximum $\mathrm{CO}_{2}$ sorption capacity on the synthesized activated carbon is found to be 80 mg $\mathrm{CO}_{2}$ per gram adsorbent. The research was indicated that the most of the researchers are working with experimental and theoretical method for pressure swing and gravimetric adsorption method with fix bed by using activated carbon or its alternatives, as an adsorption material [14]. Very few researchers are applying numerical method to predict $\mathrm{CO}_{2}$ adsorption on activated carbon bed. Nouh et al performed numerical simulation on fixed bed adsorption column using integrated approach to predict the effect of various influencing parameters such as feed velocity, bed porosity and feed concentration [15]. They investigated their influences on the $\mathrm{CO}_{2}$ adsorption capacity besides the effect of inlet $\mathrm{CO}_{2}$ concentration on the bed temperature profile. Ryan et al applied multiphase CFD modelling on solid sorbent carbon capture fluidized bed system with silica supported amine adsorbent material [16]. CFD simulation studies were carried out to determine the separation length required for complete separation of the feed mixture corresponding to different inlet feed concentrations which were entering the column at a given flow rate. Pierre recently, worked on computational investigation of $\mathrm{CO}_{2}$ capture using activated carbon in a packed bed and optimization of various parameters to improve efficiency of the process [17]. However, none of the researchers applied radiation, natural convection, species transport, multiphase and turbulent flow condition on activated carbon fix bed to simulate $\mathrm{CO}_{2}$ adsorption effect. So, these numerical parameters will be considered in this study. The commercially available CFD software Fluent 14.1 will be used for this simulation.

\section{CFD MODEL SETUP AND ANALYSIS}

\subsection{GENERAL}

The geometry was created in Ansys Design Modeler with bed size $40 \times 30 \times 0.1 \mathrm{~cm}^{3}$ fitted 
inside rectangular column having dimension $40 \mathrm{x} 40 \times 30 \mathrm{~cm}$ as shown in Figure 1.

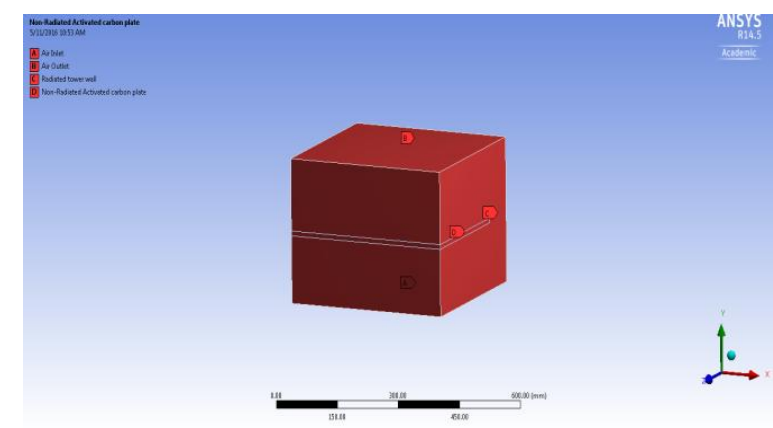

Fig 1 Schematic of the column model with feed inlet and outlet.

The domain was then meshed as shown in Figure 2 and model was subsequently set up in Ansys Fluent 14.1[18].

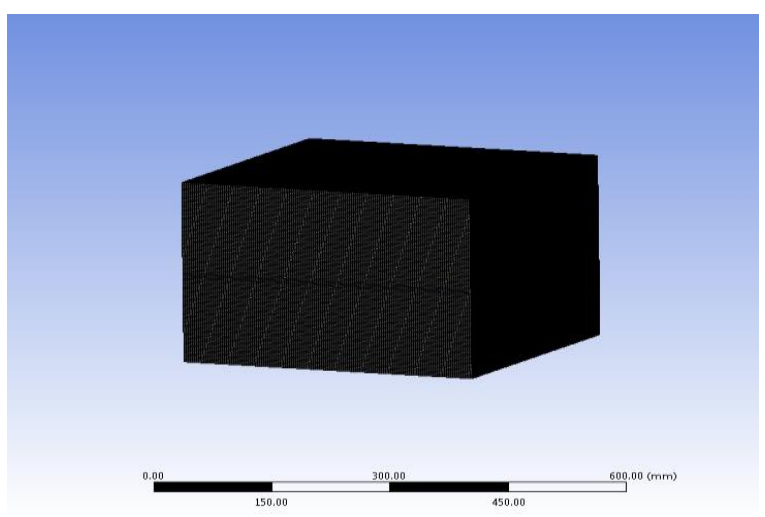

Fig. 2. Ansys Meshing of column model

The details of the adsorption column model were taken from earlier related work [17-18]. The fluid was taken to be incompressible, Newtonian, and in a turbulent flow regime with mix radiation and natural convection effects. Normal atmospheric air with $0.20 \%$ $\mathrm{H}_{2} \mathrm{O}, 0.23 \% \mathrm{O}_{2}, 0.10 \% \mathrm{CO}_{2}$ and $47 \% \mathrm{~N}_{2}$ mass fraction conditions was chosen as the feed mixture. The multi-phase Eulerian model with granular mass transfer approach was used in activated carbon domain. The simulation of the fluid flow in that fixed bed since the adsorbent inside the activated carbon packed bed can be treated as porous medium having porosity $0.42 \mathrm{~mm}$. The mixing and transport of binary species are modeled by solving conservation equations describing convection and diffusion for each component species. The following assumptions have been made in the modeling approach.

i. Heat transfer within bed is negligible.

ii. The mass transfer is represented by linear driving force (LDF) model.

iii. The porosity in granular media domain is considered as uniform throughout.

\subsection{GOVERNING EQUATION FOR ADSORPTION COLUMN}

Eulerian granular multiphase model continuity equation for phase: The general 3$\mathrm{D}$ continuity equation for unsteady fluid flow is;

$$
\frac{\partial\left(\alpha_{q} \rho_{q}\right)}{\partial t}+\nabla *\left(\alpha_{q} \rho_{q} \overrightarrow{v_{q}}\right)=\sum_{p=1}^{n}\left(m_{p q}-m_{q p}\right)+S_{q}
$$

Where $\overrightarrow{v_{q}}$ is the velocity of phase $q$ and $\boldsymbol{m}_{p q}^{\circ}$ characterizes the mass transfer from the $\mathrm{p}^{\text {th }}$ to $\mathrm{q}^{\text {th }}$ phase, and $\boldsymbol{m}_{q p}^{\circ}$ characterizes the mass transfer from phase $q$ to phase $p$, and you are able to specify these mechanisms separately. $S_{q}$ is a source term.

\subsection{CONSERVATION OF MOMENTUM}

The momentum balance for phase q yields.

$$
\begin{aligned}
& \frac{\partial\left(\alpha_{q} \rho_{q} \overrightarrow{v_{q}}\right)}{\partial t}+\nabla *\left(\alpha_{q} \rho_{q} \overrightarrow{v_{q}} \overrightarrow{v_{p}}\right) \\
& =-\alpha_{q} \nabla \mathrm{p}+\nabla * \overline{\overline{\tau_{q}}}+\alpha_{q} \rho_{q} \vec{g} \\
& +\sum_{p=1}^{n}\left(\overrightarrow{R_{p q}}+m_{p q} \cdot \overrightarrow{v_{p q}}-m_{q p} \cdot \overrightarrow{v_{q p}}\right) \\
& +\left(\overrightarrow{F_{Q}}+\overrightarrow{F_{l i f t, Q}}+\overrightarrow{F_{v m, Q}}\right)
\end{aligned}
$$

Where $\overline{\overline{\tau_{q}}}$ is the qth phase stress-strain tensor,

$$
\overline{\overline{\tau_{q}}}=\alpha_{q} \mu_{q}\left(\nabla \overrightarrow{v_{q}}+\nabla{\overrightarrow{v_{q}}}^{T}\right)+\alpha_{q}\left(\lambda_{q} \frac{2}{3} \mu_{q}\right) \nabla * \overrightarrow{v_{q}} \overline{\bar{I}}
$$

$\overrightarrow{v_{p q}}$ is the interphase velocity, defined as follows. If $m_{p q}^{\circ}>0$ (i.e., phase $p$ mass is being 
transferred to phase q), $\overrightarrow{v_{p q}}=\overrightarrow{v_{p}}$; if $m_{p q}^{\circ}<0$ (i.e., phase $\mathrm{q}$ mass is being transferred to phase p), $\overrightarrow{v_{p q}}=\overrightarrow{v_{q}}$. Likewise, if $m_{q p}^{*}>0$ then $\overrightarrow{v_{q p}}=\overrightarrow{v_{q}}$, if $m_{q p}<0$ then $\overrightarrow{v_{q p}}=\overrightarrow{v_{p}}$. Interphase force $\overrightarrow{R_{p q}}$. This force depends on the friction, pressure, cohesion, and other effects, and is subject to the conditions that $\overrightarrow{R_{p q}}=-\overrightarrow{R_{q p}}$ and $\overrightarrow{R_{q q}}=0$

$$
\sum_{p=1}^{n}\left(\overrightarrow{R_{p q}}\right)=\sum_{p=1}^{n} K_{p q}\left(\overrightarrow{v_{p}}-\overrightarrow{v_{q}}\right)
$$

Where $K_{p q}\left(=K_{q p}\right)$ is the interphase momentum exchange coefficient. For the multiphase flow the effect of lift forces were considered on the secondary phase particles. These lift forces act on a particle mainly due to velocity gradients in the primary-phase flow field. The lift force will be more significant for larger particles, but in this paper, model assumes that the particle diameter is much smaller than the inter-particle spacing. Thus, the inclusion of lift forces is not appropriate for closely packed particles or for very small particles. The lift force is insignificant compared to the drag force, so there is no reason to include this extra term. The drag coefficient is considering Syamlal-Obrien equation which is more appropriate for solid to gas phase interaction.

\subsection{Species Transport Without reaction EQUATIONS}

The local mass fraction of each species, $\mathrm{Y}_{\mathrm{i}}$, through the solution of a convection-diffusion equation for the $\mathrm{i}^{\text {th }}$ species can be predicted. This conservation equation takes the following general form:

$$
\frac{\partial}{\partial t}\left(\rho Y_{i}\right)+\nabla *\left(\rho \vec{v} Y_{i}\right)=-\nabla \cdot \overrightarrow{J_{i}}+R_{I}+S_{I}
$$

We are considering flow become turbulent so mass diffusion in the following form:

$$
\overrightarrow{J_{i}}=\left(\rho D_{i, m}+\frac{\mu_{t}}{S c_{t}}\right) \nabla Y_{i}
$$

No special solution procedures are usually required for a non-reacting species transport calculation.

\subsection{DISCRETE ORDINATES (DO) RADIATION MODEL}

The discrete ordinates (DO) radiation model solves the radiative transfer equation (RTE) for a finite number of discrete solid angles. The DO model considers the radiative transfer equation (RTE) in the direction $s$ as a field equation.

$$
\begin{aligned}
& \nabla \cdot(I(\vec{\gamma}, \vec{S}) \vec{S})+\left(a+\sigma_{s}\right) I(\vec{\gamma}, \vec{S}) \\
= & a n^{2} \frac{\sigma T^{4}}{\pi}+\frac{\sigma_{s}}{4 \pi} \int_{0}^{4 \pi} I\left(\vec{\gamma}, \overrightarrow{s^{t}}\right) \Phi\left(\vec{S} \cdot \vec{S}^{t}\right) d \Omega^{t}
\end{aligned}
$$

\subsection{SIMULATION BOUNDARY CONDITION}

The simulation domain operated at 1 bar pressure and $303 \mathrm{~K}$ temperature. Same boundary condition set at wall to define natural convection. The atmospheric air inlet velocity is set at $0.1 \mathrm{~m} / \mathrm{s}$ with $0.20 \% \mathrm{H}_{2} \mathrm{O}$, $0.23 \% \mathrm{O}_{2}, 0.10 \% \mathrm{CO}_{2}$ and $47 \% \mathrm{~N}_{2}$ mass fraction.

\section{RESULTS AND DISCUSSION}

The integrated CFD model was used to determine $\mathrm{CO}_{2}$ mass fraction at the column outlet for different time based on set operating conditions. The results simulated using the CFD model. Based on the good agreement of the model results as shown in Figure 3, which was useful to study the effect of $\mathrm{CO}_{2}$ concentration on the adsorption performance. It is clearly presented that $\mathrm{CO}_{2}$ mass concentration is gradually decreasing with increasing height of the column. 


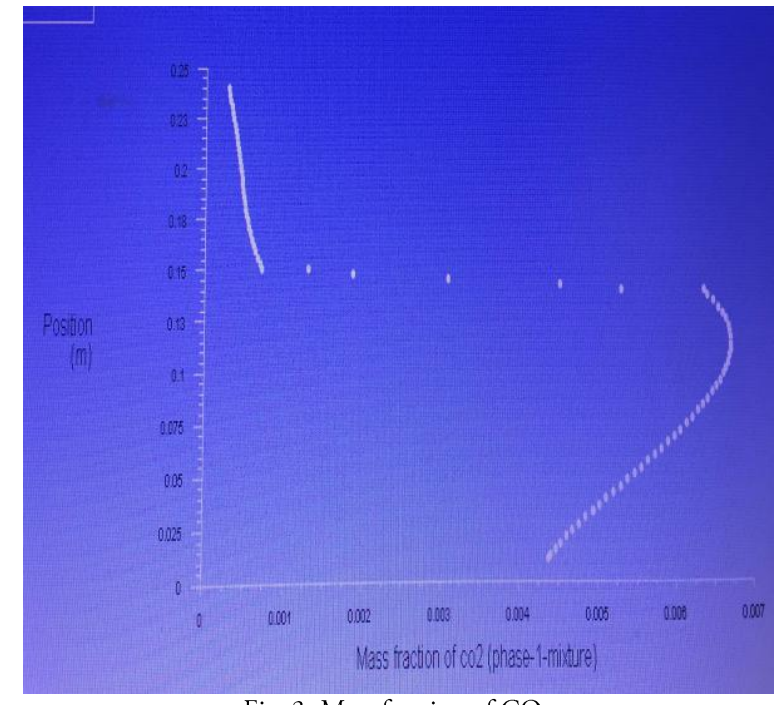

Fig. 3. Mass fraction of $\mathrm{CO}_{2}$

\section{CONCLUSION}

The CFD simulation is a useful tool to conceptual system design and testing. It is helpful to predict the $\mathrm{CO}_{2}$ mass fraction with single activated carbon adsorbed plate. The result was presented an equitable mode for the effect of feed velocity, bed porosity and $\mathrm{CO}_{2}$ inlet concentration on single stack of activated carbon. This study also showed that the effect of granular bed significantly influences the performance and capability of the adsorption process. Hence, it is completely justify our concept.

\section{ACKNOWLEDGEMENTS}

The simulation was performed at Yanbu Research Center, Computational Lab. Yanbu, Kingdom of Saudi Arabia.

\section{REFERENCES}

[1] B. Metz, 2005, Intergovernmental Panel on Climate Change. Special Report on Carbon Dioxide Capture and Storage Cambridge University Press, Cambridge.

[2] H. Pahlaranzadeh, A. R. Jahangiri, I. Noshadi, 2012, Modelling of $\mathrm{CO}_{2}$ removal from gas mixture by 2-amino-2-methyl-1-propanol(AME) using the modified Kent Eisenberg Model. International Journal of Chemical, Molecular,
Nuclear, Materials and Metallurgical Engineering, Vol:6, pp. 664-669.

[3] J. F. Vivo-Vilches, E. Bailon-Garcia, A. F. PerezCadenas, F. Carrasco-Marin, F. J. MaldonadoHodal, 2014, Tailoring the surface chemistry and porosity of activated carbons: Evidence of reorganization and mobility of oxygenated surface groups, Carbon, Volume 68, pp. 520-530.

[4] S. Jhadhav, 2015, Value Added Products from Gasification - Activated Carbon. The Combustion, Gasification and Propulsion Laboratory (CGPL) at the Indian Institute of Science (IISc). Retrieved 2015 April 30.

[5] Y. Takeuchi, A. Shigeta, H. Iwamoto, 1993, Adsorption of solvent vapor mixture in air by activated carbon fiber bed, Separation Technology. Volume 3, pp. 46-52.

[6] J. N. Baleo, A. Subrenat, P. Le Cloirec, 2000, Numerical Simulation of flows in air treatment devices using activated carbon cloths filters, Chemical Engineering Science, 55, pp. 18071816

[7] B. Guo, L. Chang, K. Xie, 2006, Adsorption of Carbon Dioxide on Activated Carbon, Journal of Natural Gas Chemistry, Volume 15, pp. 223-229.

[8] C. Shen, J. Yu, P. Li, C. A. Grande, A. E. Rodrigues, 2011, Capture of $\mathrm{CO}_{2}$ from flue gas by vacuum pressure swing adsorption using activated carbon beads, Adsorption, Volume 17, pp. 179-188.

[9] V. Goetz, O. Pupier, A. Guillot, 2006, Carbon dioxide-methane mixture adsorption on activated carbon, Adsorption Volume 12, pp. 55-63.

[10] C. Pevida, M. G. Plaza, B. Arias, J. Fermoso, F. Rubiera, J. J. Pis, 2008, Surface modification of activated carbons for $\mathrm{CO}_{2}$ capture, Applied Surface Science, Volume 254, pp. 7165-7172.

[11] A. H. Berger, A. S. Bhown, 2013, Optimizing Solid Sorbents for $\mathrm{CO}_{2}$ Capture Energy Procedia, Volume 37, pp. 25-32.

[12] D. P. Bezerra, R. S. Oliveira, R. S. Vieira, C. L. Cavalcante Jr, C. S. Azevedo, 2011, Adsorption of $\mathrm{CO}_{2}$ on nitrogen enriched activated carbon and zeolite 13X, Adsorption Volume 17, pp. 235-246.

[13] L. Hauchhum, P. Mahanta, 2014, Carbon dioxide adsorption on zeolites and activated carbon by pressure swing adsorption in a fixed bed Int J Energy Environ Eng, Volume 5, pp. 349-356. 
[14] N. A. Rashidi, S. Yusup, L. H. Loong, 2013, Kinetic Studies on Carbon Dioxide Capture using Activated Carbon Chemical Engineering Transactions, Volume 35, pp. 361-366.

[15] S.A Nouh, K. K. Lau, A. M. Shariff, 2010, Modeling and Simulation of Fixed Bed Adsorption Column using Integrated CFD Approach Journal of Applied Sciences, Volume 10, pp. 3329-3235.
[16] E.M. Ryan, D. DeCroix, R. Breault, W. Xu, E. D. Huckaby, K. Saha, S. Dartevelle, X. Sun, 2013, Multi-phase CFD modeling of solid sorbent carbon capture system Powder Technology, Volume 242,pp. 117-134.

[17] H. S. Pierre, 2005, Simulation of dynamic pressure-swing gas sorptionin polymers, Master's Thesis University of Maryland.

[18] ANSYS USER'S GUIDE 2016. 


\title{
دراسة ديناميكا الموائع حسابياً لمرشحات الهواء الكربونية العاملة بالطاقة الثمسية
}

\author{
إبر اهيم محمد عوض مصطفى1، كارنل باتل2، خالد الزهر اني2 \\ 1 قسم المهار ات الكيميائية، معهد ينبع التقني، مدينة ينبع الصناعية، المملكة العربية السعودية \\ $2{ }^{2}$ \\ 3 قسم تكنولوجيا الهندسة الميكانيكية ومركز ينبع للبحوث، مدينة ينبع الصناعية، المملكة العربية السعودية
}

الملخص:

ان الطاقة الثمسية هي لغة هذا العصر، وهي طاقة متجددة ونظيفة وبدون تكلفة تقريبا، لذلك يركز هذا البحث على استخدام الطاقة الثمسية في عملية تنقية الهواء. وكما هو معلوم، فإن بيئتنا مليئة بغاز ات النفايات الصناعية، مثل أكاسيد الكبريت و أكاسيد النيتروجين و أكاسيد الكربون والميثان وكبريتيد الهيدروجين .... الخ. ولتقليل نسبة تركيز هذه الغازات تستخدم الطاقة الثمسية لتوليد تيار حمل حراري داخل برج معدني أسود (لامتصاص اكبر قدر ممكن من الطاقة الثمسية). حيث يمر الهواء الملوث المتكون من غاز ات النفايات الصناعية من خلال البرج لتصطدم اثثاء صعودها مع حواجز من لوحات الكربون المنشط المثبتة أفقيا على جانبين متقابلين من البرج بحيث يتم امتزاز هذه الغاز ات على اسطح هذه الالو اح و المكونة من حبييات الكربون المنشط المضغوطة، حيث يتمتع الكربون المنشط بقدرة امتصاص هائلة. لذلك سوف يعمل على إز الة غازات النفايات من الهواء الملوث. ولضمان الحصول على نتائج دقيقة لتغيير قيم تركيز الغازات الضارة (ممثلة بغاز ثاني اكسيد الكربون في هذا Navier- البحث) مع تغيير الإرتفاع داخل البرج، فقد نم حل معادلات النموذج: استمر ارية الحالة ثلاثية الأبعاد، Stokes ، الطاقة، الإشعاع، الحمل الحراري الطبيعي، نقل الأنواع للامتزاز الفيزيائي لثاني أكسبد الكربون، Computational Fluid Dynamics في ظل حالة مضطربة، وذلك باستخدام برنامج Eulerian-granular software Fluent

مقبول مما يثبت أن ديناميكيات الموائع الحسابية أداة فعالة للتنبؤ بسلوك و أداء فلتر الهو اء الثمسي. 